\title{
Low-Cost Adsorbents procedure by means of Heavy Metal Elimination from Wastewater
}

\author{
Baby Abrarunnisa Begum*1, Dr.N Devanna*2, Dr.M A Chari*3 \\ ${ }^{1}$ Associate Professor, Chemistry Department, SWCET, Hyderabad, Telangana, India \\ ${ }^{2}$ Professor \& Head, Chemistry Department, JNTUA, Anantapuram, A.P., India \\ 3*R \& D Director of Dr Macs Bio-Pharma Pvt Ltd Hyderabad Telangana \\ abrarunnisa@gmail.com, devanna.chemistry@jntua.ac.in, drmacs36@gmail.com
}

\begin{abstract}
The beginning of industrialization human being has observed a variety of environmental troubles in the world. This industrialization has not only brought growth and affluence but ultimately troubled the ecosystem. One of the crashes is visible, in form of water contamination. Here the current study heavy metal contamination of water body has been discussed. Effluents from a great number of industries viz., tannery, textile, pigment \& dyes, paint, wood processing, petroleum refining, electroplating, leather etc., have a major amount of heavy metals in their wastewater. The conventional technique of handling heavy metal pollution includes chemical oxidation, chemical precipitation, ion exchange, reverse osmosis, membrane separation, electrodialysis etc. These processes are expensive, energy intensive and frequently related with generation of poisonous by-product. Therefore, the adsorption has been examined as a cost-efficient technique of elimination of heavy metals from wastewater. In the current study different low-cost adsorbent has been a review as an abatement of heavy metal contamination from wastewater. These adsorbent comprise materials of natural origin like peat moss, zeolites, clay, and chitin are found to be an effective agent for removal of deadly heavy metals like $\mathrm{Pb}, \mathrm{Cd}, \mathrm{Zn}, \mathrm{Cu}, \mathrm{Ni}, \mathrm{Hg}, \mathrm{Cr}$ etc. Separately from these, a variety of agricultural wastes like rice husk, waste tea, neem bark, black gram; Turkish coffee, walnut shell etc. were also known as a powerful adsorbent for heavy metal removal. at the side of that low-cost industrial byproduct like fly ash, lignin, iron (III) hydroxide and red mud, coffee husks, Areca waste, tea factory waste, sugar beet pulp, battery industry waste, blast furnace sludge, waste slurry, sea nodule remains and grape stalk wastes have been discovered for their technical possibility to eliminate toxic heavy metals from impure water.
\end{abstract}

Keywords: Heavy metal; Agricultural waste; Low cost adsorbent; Wastewater; Toxicity Introduction

Water contamination caused due to the addition of heavy metals ensuing from the industrial activities is rising extremely and is a matter of global worry. Mining, mineral dispensation, and metallurgical process are generating effluents hold heavy metals. The heavy metals here in the wastewater is unrelenting and nondegradable in natural world furthermore, they are soluble in aquatic surroundings and therefore can be simply absorbed by living cells. Thus, by incoming the food chain, they can be bioaccumulated and biomagnified in higher trophic level also. The heavy metals, if absorbed over the allowable labels, could lead to severe health problems. In light of the details, cure of heavy metals holds industrial effluent becomes quite essential earlier than being released into the environment. The conventional methods for heavy metal elimination from wastewater contain chemical precipitation, chemical oxidation, ion exchange, membrane separation, reverse osmosis, electrodialysis etc. These techniques are not effective, 
are costly and require high energy contribution. They are linked with the generation of toxic sludge, removal of which render it costly and non-ecofriendly in an environment. In the current past, numeral move toward has been investigated for the secure and inexpensive treatment of heavy metal-laden wastewater. Adsorption has appeared out to be an improved alternative treatment technique. It is said to be successful and economical because of its relatively low cost. Authors have asserted adsorption to be an easiest, safest and most cost-effective process for the treatment of waste effluents hold heavy metals $[1,2]$. The advantage of the adsorption process for heavy metal elimination is fewer initial as well as process costs, simple design and fewer requirements of control systems [3]. Generally, the heavy metals are there in the wastewater at low concentrations and adsorption is suitable even when the metal ions are there at concentrations as low as $1 \mathrm{mg} / \mathrm{L}$. This makes adsorption an inexpensive and favorable technology for heavy metal elimination from wastewater. The adsorbent might be of the mineral, organic or biological source. It might be industrial byproducts, zeolites, agricultural waste, biomass, and polymeric material. One of the conventional adsorbents, activated carbon has been widely used in numerous applications. Though, the high-cost effectiveness of activation processes limits its practice in the wastewater treatment procedure. The current research action aims toward contributing to look for cost-effective or low-cost adsorbents of natural origin and their applicability in recovery as well as the elimination of heavy metals from the industrial wastewater.

\section{Heavy Metals and Industrial Ravage water}

Heavy metals are usually free in the wastewater from a variety of industries. Electroplating and surface treatment practice lead to the creation of significant quantities of wastewater hold heavy metals (such as chromium, nickel, copper, vanadium, platinum, cadmium, zinc, lead, silver and titanium). Separately from this wastewater from pigment, leather, tannery, textile $\&$ dyes, paint, wood processing, petroleum refining industries, and photographic film production contain a major amount of heavy metals. These heavy metal ions are poisonous to both human beings and animals. The toxic metals cause physical distress and sometimes life-threatening sickness and permanent damage to vital body system [4]. The metals get bio-accumulated in the aquatic environment and tend to bio-magnified along the foodstuff series.

Therefore, the organisms at the superior trophic stage are more vulnerable to be pretentious by their toxicity. Here are some 20 metals which are almost determined and cannot be degraded or shattered. Mercury ( $\mathrm{Hg}$ ), lead (Pb), cadmium (Cd), chromium (Cr [VI]), Zinc (Zn), Arsenic (As), Nickel (Ni) etc., are toxic heavy metals from an ecotoxicological point of view. The table below shows Maximum Contaminant Level (MCL) standards for some heavy metals recognized by USEPA [5]. These heavy metals can lead to severe effects such as stunted growth, harm to very important organs, injury to the brain, cancer and in some cases death may also occur. Health hazard associated with heavy metal toxicity is not new. Human being diseases like Minamata, Itai, fluorosis, Arsenicosis etc. are due to heavy metal ingestion above allowable levels. Care for the industrial effluents polluted with heavy metals within the industrial location before being discharged is a well-organized way to eliminate heavy metals rather than treating a high volume of wastewater in an all-purpose sewage treatment plant. Therefore it is beneficial to expand separate handling modus operandi for taking away of heavy metals from the industrial effluents. The present job focuses on the study of natural coagulants as an effective and economical alternative treatment procedure for heavy metals removal from industrial wastewater. (Table 1) 


\begin{tabular}{|l|l|l|}
\hline Heavy metal & \multicolumn{1}{|c|}{ Toxic } & MCL(mg/L) \\
\hline Arsenic(As) & $\begin{array}{l}\text { Skin manifestations, visceral cancers, } \\
\text { vascular disease }\end{array}$ & 0.020 \\
\hline Cadmium(Cd) & $\begin{array}{l}\text { Kidney damage, renal disorder, human } \\
\text { carcinogen }\end{array}$ & 0.01 \\
\hline Chromium(Cr) & $\begin{array}{l}\text { Headache, diarrhea, nausea, vomiting, } \\
\text { carcinogenic }\end{array}$ & 0.04 \\
\hline Copper(Cu) & Liver damage, Wilson disease, insomnia & 0.23 \\
\hline Nickel(Ni) & $\begin{array}{l}\text { Dermatitis, nausea, chronic asthma, coughing, } \\
\text { human carcinogen }\end{array}$ & 0.21 \\
\hline Zinc(Zn) & $\begin{array}{l}\text { Depression, lethargy, neurological signs and } \\
\text { increased thirst }\end{array}$ & 0.70 \\
\hline Lead(Pb) & $\begin{array}{l}\text { Damage the fetal brain, diseases of kidney, } \\
\text { circulatory system and nervous system }\end{array}$ & 0.005 \\
\hline Mercury(Hg) & $\begin{array}{l}\text { Rheumatoid arthritis and disease of kidneys } \\
\text { circulatory and nervous system }\end{array}$ & 0.00002 \\
\hline
\end{tabular}

Table The MCL standards for the most Hazardous heavy metals [5].

\section{Adsorption}

As discuss about previous, adsorption has appeared out as a successful, economical and ecofriendly treatment method. It is a powerful process enough to accomplish water recycles compulsion and high effluent standards in the industries. Adsorption is a mass transfer method by which a substance is transfer from the liquid phase to the surface of a solid, and becomes bound by physical and/or chemical interactions [5]. It is a division process in which few components of the liquid phase are repositioned to the surface of the solid adsorbents. All adsorption process is dependent on solid-liquid equilibrium and on mass transfer rates. The adsorption process can be batch, semi-batch and continuous. At a molecular level, adsorption is mostly due to attractive interfaces between a surface and the group being absorbed. Depending upon the kind of intermolecular attractive forces adsorption could be of following types:

\section{Physical Adsorption}

It is a common incident and occurs in any solid/liquid or solid/gas system. Physical adsorption is a method in which binding of adsorbate on the adsorbent surface is occurred by van der Waals forces of attraction. The electronic structure of the atom or molecule is almost not disturbed 


\section{Chemical Adsorption}

This type of adsorption involves a chemical reaction between the adsorbent and the adsorbate. The strong interface among the adsorbate and the substrate surface creates new types of electronic bonds (Covalent, Ionic). Chemical adsorption is also known to as activated adsorption. The adsorbate can form a monolayer. It is utilized in catalytic operations. In common, the main steps involved in adsorption of pollutants on solid adsorbent are Transfer of the toxin from the bulk solution to the external surface of the adsorbent.

Inner mass transfer by pore diffusion from the external surface of adsorbent to the inner surface of the leaky structure. Adsorption of adsorbate on the active sites of the holes of adsorbent. In general rate of adsorption is determined by either film formation or intraparticle diffusion or both as the last step of adsorption are rapid as compared to the remaining two steps.

\section{Low-Cost Adsorbents}

By using low-cost adsorbent to remove heavy metals it is more hopeful in extended terms as there are numerous materials accessible locally and plentifully such as natural materials, industrial by-products or agricultural wastes which can be used as low-cost adsorbents [6]. To be commercially viable, an adsorbent must have high selectivity to make easy quick separations, good transport, and kinetic feature, thermal and chemical stability, and mechanical strength, confrontation to fouling, revival capacity and little solubility in the liquid in contact. Adsorption technique has many advantages over the conventional technique of heavy metal elimination. Some of the gains of adsorption method are (I) Economical, (II) metal selectivity, (III) Regenerative, (IV) Absence of toxic sludge generation (V) metal recovery and most importantly (VI) effective. a variety of low-cost adsorbent resulting from a range of natural as well as anthropogenic sources has been implemented for the treatment of wastewater contaminated with heavy metals. The adsorbents typically used are the agricultural waste, industrial byproducts, natural materials or modified biopolymers

\section{Adsorption by Natural Materials (Zeolites)}

The naturally occurring crystalline aluminosilicates are consist of the skeleton of tetrahedral molecules associated with mutual oxygen atoms connect with each other. The ions exchange capacity of zeolites builds them an appropriate applicant for the elimination of heavy metals. Adsorption in the zeolite, in fact, a particular and reversible stuffing of crystal cages, so surface area is not an important aspect. Zeolites consist of a broad range of species such as clinoptilolite and chabazite. Amongst the dissimilar zeolites, clinoptilolite has been widely studied and was 
shown to have high selectivity for metals like $\mathrm{Pb}$ (II), $\mathrm{Cd}$ (II), $\mathrm{Zn}$ (II) and $\mathrm{Cu}$ (II). a number of zeolites are customized throughout the earlier period a few years to boost their efficiency. Clinoptilolite was found to be more effectively removing heavy metals owing to its ion exchangeability, followed by pretreatment $[5,7]$.

\section{Clay}

The three major group of clays: montmorillonite-smectite, kaolinite, and mica. The montmorillonite has the maximum cation switch capacity and its fresh market value found to be 20 times lesser as compared to activated carbon. Their heavy metals elimination capacity is very less as compare to zeolites but their easy accessibility and economical properties give back their less competence. Efficiency for heavy metal removal by clay could be better by changing them to clay-polymer composites [8-10]

\section{Peat moss}

Plentiful in nature and has a very lofty organic content. Its big surface area ( $\geq 200 \mathrm{~m} 2 / \mathrm{g})$ and high porosity make it an effectual agent for heavy metal elimination from wastewater. It was seen that peat moss plays a significant role in the treatment of metal-bearing industrial effluents such as $\mathrm{Cu} 2+, \mathrm{Cd} 2+, \mathrm{Zn} 2+$, and $\mathrm{Ni} 2+[11]$. The adsorption ability of sphagnum peat moss was found to be $128 \mathrm{mg}$ of $\mathrm{Cr} 6+/ \mathrm{g}$ at a $\mathrm{pH}$ range of 1.2-2.7. The most conspicuous advantage of this adsorbent in treatment is the easiness of the system, low cost, and the ability to admit a wide difference of effluent composition [12].Chitin: It is the next most profuse natural biopolymer followed by cellulose. Chitin is a long-chain polymer of N-acetyl glucosamine, a imitative of glucose. It is the main part of the cell walls of fungi, the exoskeletons of arthropods such as crustaceans (e.g. lobsters, crabs, shrimps) and insects. It is used for the elimination of numerous heavy metals in the past. Currently, Chitosan, which is produced by alkaline Ndeacetylation of chitin, is drawing an increased amount of study interest for its heavy metal removal capability due to chelating property. It can be ready by treating shrimp and other crustacean shells with the alkali sodium hydroxide. Chitosan has been used for the treatment of $\mathrm{Hg}^{2}+, \mathrm{Cu}^{2}+, \mathrm{Ni}^{2}+, \mathrm{Zn}^{2}+, \mathrm{Cr}^{6}+, \mathrm{Cd}^{2}+$, and $\mathrm{Pb}^{2}+$.

\section{Adsorption by Agricultural Wastes}

Using as adsorbents of agriculture by-products for removal of heavy metals from wastewater it is increased these days. Number of studies has been focused On waste of plants mainly neem bark rice husk[13,14], Black gram husk [15],tea waste, Walnut shell [16] etc. a few more adsorbents like papaya wood [17], maize leaf [18], teak leaf powder [19], coraindrum sativum [20], lalang (Imperata cylindrica) leaf powder [21], peanut hull pellets [22], sago waste [23], saltbush (Atriplex canescens) leaves [24,25], tree fern [26-28], grape stalk wastes [29], etc. are also study in aspect. The advantages of use of agriculture waste for wastewater treatment comprise simple method, wants modern methods better adsorption skill, and selective adsorption of heavy metal ions, Most of the studies were convene on plant wastes like rice husk and neem bark [13,14], Black gram husk [15], Waste tea, Turkish coffee, Walnut shell [16] etc. a few more adsorbents like papaya wood [17], maize leaf [18], teak leaf powder [19], coraindrum sativum [20], lalang (Imperata cylindrica) leaf powder [21], peanut hull pellets 
[22], sago waste [23], saltbush (Atriplex canescens) leaves [24,25], tree fern [26-28], grape stalk wastes [29], etc. are also studied in detail. The benefits of using agricultural wastes for wastewater treatment include easy technique, needs modest processing, superior adsorption ability, and selective adsorption of heavy metal ions, Inexpensive, easy availability and easy revival. On the other hand, the use of raw agricultural wastes as adsorbents can also obtain a number of harms such as small adsorption ability, eminent chemical oxygen demand (COD) and biological chemical demand (BOD) as well as total organic carbon (TOC) due to free of soluble organic compounds contained in the plant materials [30,31]. The increase in COD, BOD, and TOC can cause reduction of dissolved oxygen (DO) content in water and can make threats to the aquatic life. Therefore, plant Wastes require to be modified or treated ahead of being applied for the Cleansing of heavy metals. Wheat bran, a by-product of wheat milling industries show to be a good quality adsorbent for elimination of numerous types of heavy metal ions which finally results in better efficiency of adsorption of copper ions as reported by Ozer et al. [32]. Orange peel can be use for Ni (II) removal from replicated wastewater [33]. likewise, Adsorption of divalent heavy metal ions mainly $\mathrm{Cu} 2+, \mathrm{Zn} 2+, \mathrm{Co} 2+, \mathrm{Ni} 2+\mathrm{Pb} 2$ onto acid and alkali treated banana and orange peels was performed by Annadurai et al. in 2002 [34].Activated Coconut shell carbon powder (ACSCP) and Activated charcoal powder (ACP) is Use as adsorbent for removal of Lead from electrochemical industry Effluent [35]. Furthermore, factor like $\mathrm{pH}$, temperature, Contact time, initial concentration of metal, agitation rate, dosage of Adsorbent etc. affects the adsorption capacity [36].

\section{Adsorption by Industrial Wastes}

A variety of industrial wastes also has adsorption capacity and it can be use for adsorbing heavy metals from wastewater. These industrial wastes are formed as a by-product and are used hardly ever for any reason. The by-product nature renders it to be simply accessible and very cheap also. These industrial wastes are originated to have good use as adsorbent. Adsorptive capacity of these wastes could be enlarged followed by slight dispensation. Industrial by-products such as fly ash [37, 38], blast furnace sludge [39, 40], waste slurry, lignin-a black liquor waste of paper industry [41, 42, 43], iron (III) hydroxide [44, 45] and red mud [46,47] have been explore for their technical possibility to eliminate toxic heavy metals from impure water. Some adsorbents have been used for adsorption of Zinc from waste water. Some of the highest adsorption capacities reported for $\mathrm{Zn} 2+$ are $168 \mathrm{mg} / \mathrm{g}$ powdered waste sludge, $128.8 \mathrm{mg} / \mathrm{g}$ dried marine green microalgae, $73.2 \mathrm{mg} / \mathrm{g}$ lignin, $55.82 \mathrm{mg} / \mathrm{g}$ cassava waste, and $52.91 \mathrm{mg} / \mathrm{g}$ bentonite [48]

\section{Conclusion}

The fresh universal trend to attain advanced environmental principles favors the usage of low cost system for treatment of effluents. In the interim a variety of low cost adsorbent resulting from agricultural waste or natural products have been widely examine for heavy metal removal from infected wastewater. It has been found that after chemical or thermal change, agricultural waste exhibited tremendous heavy metal removal capability. Concentration of adsorbate, extent of surface alteration and adsorbent Characteristics are the factors responsible for metal adsorption capability. Cost Effectiveness and technical applicability are the two significant key factors for selecting effective low cost adsorbent for heavy metal elimination 


\section{Acknowledgement}

Author would like to acknowledge the motivation and facilities provided by

Dr M A Chari, Dr M Shobha, Director Dr Macs Bio-Pharma to carry out the present work.

\section{References}

1. Shah BA, Shah AV, Singh RR (2009) Sorption isotherms and kinetics of chromium uptake from wastewater using natural sorbent material. International Journal of Environmental Science and Technology 6: 77-90.

2. Rahmani K, Mahvi AH, Vaezi F, Mesdaghinia AR, Nabizade R, et al (2009) Bioremoval of lead by use of waste activated sludge. International Journal of Environmental Research, 3: 471-476.

3. Acar FN, Eren Z (2006) Removal of Cu (II) ions by activated poplar sawdust (Samsun Clone) from aqueous solutions. J Hazard Mater B 137: 909-914.

4. Malik A (2004) Metal bioremediation through growing cells. Environmental International, 30: 261-278.

5. Babel S, Kurniawan TA (2003) Various treatment technologies to remove arsenic and mercury from contaminated groundwater: an overview. In: Proceedings of the First International Symposium on Southeast Asian Water Environment, Bangkok, Thailand, 2425 October: 433-440.

6. Siti Nur AA, Mohd Halim SI, Lias Kamal Md, Shamsul Izhar (2013) Adsorption Process of Heavy Metals by Low-Cost Adsorbent: A Review. World Applied Sciences Journal 28: 1518-1530.

7. Bose P, Bose MA, Kumar S (2002) Critical evaluation of treatment strategies involving adsorption and chelation for wastewater containing copper, zinc, and cyanide. Adv Environ Res 7: 179-195.

8. Vengris T, Binkiene R, Sveikauskaite A (2001) Nickel, copper, and zinc removal from wastewater by a modified clay sorbent. Appl Clay Sci 18:183-90.

9. Solenera M, Tunalib S, O“zcan ,A S, O“zcanc A, Gedikbey T (2008) Adsorption characteristics of lead (II) ions onto the clay/ poly(methoxyethyl)acrylamide (PMEA) composite from aqueous solutions. Desalination 223: 308-322.

10. Abu-Eishah SI (2008) Removal of $\mathrm{Zn}, \mathrm{Cd}$, and $\mathrm{Pb}$ ions from water by Sarooj clay. Appl Clay Sci $42: 201-205$

11. Gosset T, Trancart JL, Thevenot DR (1986) Batch Metal removal by peat Kinetics and thermodynamics. Water Res 20: 21-26.

12. Sharma DC, Forster CF (1993) Removal of Hexavalent Chromium using Sphagnum moss peat. Water Res 27: 1201-1208.

13. El-Said AG, Badawy NA, Garamon SE (2012) Adsorption of Cadmium (II) and Mercury (II) onto Natural Adsorbent Rice Husk Ash (RHA) from Aqueous Solutions: Study in Single and Binary System, International Journal of Chemistry 2012: 58-68.

14. Bhattacharya AK, Mandal SN, Das SK (2006) Adsorption of Zn(II) from aqueous solution by using different adsorbents. Chem Eng J 123: 43-51.

15. Saeed A, Iqbal M (2003) Bioremoval of cadmium from aqueous solution by black gram husk (Cicer arientinum). Water Res 37: 3472-3480. 
16. Orhan Y, Büyükgüngör H (1993) The removal of heavy metals by using agricultural wastes. Water Sci Technol 28(2): 247-255.

17. Saeed A, Iqbal M, Akhtar MW (2005) Removal and recovery of heavy metals rom aqueous solution using papaya wood as a new biosorbent. Sep. Purif Technol 45: 25-31.

18. Babarinde NAA, Oyebamiji Babalola J, Adebowale Sanni R (2006) Biosorption of lead ions from aqueous solution by maize leaf. Int. J Phys Sci 1: 23-26.

19. King P, Srivinas P, Prasanna Kumar Y, Prasad VSRK (2006) Sorption of copper (II) ion from aqueous solution by Tectona grandis 1.f. (teak leaves powder). J Hazard Mater B136: 560-566.

20. Karunasagar D, Balarama Krishna MV, Rao SV, Arunachalam J (2005) Removal of preconcentration of inorganic and methyl mercury from aqueous media using a sorbent prepared from the plant Coriandrum sativum. J. Hazard Mater B 118: 133-139.

21. Hanafiah MAK, Ngah WSW, Zakaria H, Ibrahim SC (2007) Batch study of liquid-phase adsorption of lead ions using Lalang (Imperata cylindrica) leaf powder. J Biol Sci 7: 222230.

22. Johnson PD, Watson MA, Brown J, Jefcoat IA (2002) Peanut hull pellets as a single use sorbent for the capture of $\mathrm{Cu}$ (II) from wastewater. Waste Manage 22: 471-480.

23. Quek SY, Wase DAJ, Forster CF (1998) The use of sago waste for the sorption of lead and copper. Water SA 24: 251-256.

24. Sawalha MF, Peralta-Videa JR, Romero-Gonza'lez J, Duarte-Gardea M, Gardea-Torresdey JL (2007) Thermodynamic and isotherm studies of the biosorption of $\mathrm{Cu}(\mathrm{II}), \mathrm{Pb}(\mathrm{II})$, and $\mathrm{Zn}$ (II) by leaves of saltbush(Atriplex canescens). J Chem. Thermodyn 39: 488-492.

25. Sawalha MF, Peralta-Videa JR, Romero-Gonza'lez J, Gardea-Torresdey JL (2007) Biosorption of $\mathrm{Cd}$ (II), $\mathrm{Cr}$ (III), and $\mathrm{Cr}$ (VI) by saltbush (Atriplex canescens) biomass: thermodynamic and isotherm studies. J Colloid Interface Sci 300: 100-104.

26. Ho YS, Wang CC (2004) Pseudo-isotherms for the sorption of cadmium ion onto tree fern. Process Biochem. 39: 759-763.

27. Ho YS, Chiu WT, Hsu CS, Huang CT (2004) Sorption of lead ions from aqueous solution using tree fern as a sorbent. Hydrometallurgy. 73: 55-61.

28. Ho YS (2003) Removal of copper ions from aqueous solution by tree fern. Water Res 37: 2323-2330.

29. Villaescusa I, Fiol N, Martínez N, Miralles N, Poch J, et al. (2004) Removal of copper and nickel ions from aqueous solutions by grape stalks wastes. Water Research. 38: 992-1002.

30. Gaballah I, Goy D, Allain E, Kilbertus G, Thauront J (1997) Recovery of copper through decontamination of synthetic solutions using modified barks. Met Metall Trans.B 28: 1323.

31. Nakajima A, Sakaguchi T (1990) Recovery and removal of uranium by using plant wastes. Biomass 21: 55-63.

32. Ozer A, Ozer D (2004) The adsorption of copper (II) ions onto dehydrated wheat bran (DWB): determination of equilibrium and thermodynamic parameters. Process Biochem 39: 2183-2191.

33. Ajmal M, Rao RAK, Ahmad R, Ahmad J (2000) Adsorption studies on Citrus reticulata (fruit peel of orange) removal and recovery of Ni (II) from electroplating wastewater. $\mathrm{J}$ Hazard Mater 79: 117-31.

34. Annadurai G, Juang HS, Lee DJ (2002) Adsorption of heavy metal from water using banana and orange peels. Water Sci Technol 47: 185-190. 
35. Nishigandha JB, Suryavanshi AA, Tirthakar SN (2015) Removal of heavy metal lead (pb) from electrochemical industry waste water using low cost adsorbent. Int $\mathrm{J}$ Research in Engineering and Technology 04: 731-733.

36. Parmar M, Thakur Lokendra Singh (2013) Heavy metal Cu, Ni and Zn: toxicity, health hazards and their removal techniques by low cost adsorbents: a short overview. Int J Plant Animal \& Env. Science 3: 143-147.

37. Bayat B (2002) Combined removal of zinc (II) and cadmium (II) from aqueous solutions by adsorption onto high-calcium Turkish Fly Ash. Water Air Soil Pollut. 136: 69-92.

38. Wang SB, Li L, Zhu ZH (2007) Solid-state conversion of fly ash to effective adsorbents for $\mathrm{Cu}$ removal from wastewater. J Hazard. Mater 139: 254-259.

39. Dimitrova SV (1996) Metal sorption on blast-furnace slag. Water Res. 30: 228-232.

40. Srivastava S, Gupta V, Mohan D (1997) Removal of Lead and Chromium by Activated Slag-A Blast-Furnace Waste. J Environ Eng, 123: 461-468.

41. Suhas, Carrott PJM, Ribeiro Carrott MML (2007) Lignin-from natural adsorbent to activated carbon: A review Bioresour Technol 98: 2301-2312.

42. Srivastava SK, Singh AK, Sharma A (1994) Studies on the uptake of lead and zinc by lignin obtained from black liquor-a paper industry waste material. Environ Technol 15: 353-361.

43. Demirbas A (2004) Adsorption of lead and cadmium ions in aqueous solutions into modified lignin from alkali glucerol delignification. $\mathrm{J}$ of hazard Mater, 109: 221-226.

44. Namasivayam C, Ranganathan K (1993) Waste Fe (III)/Cr (III) hydroxide as adsorbent for the removal of $\mathrm{Cr}$ (VI) from aqueous solution and chromium plating industry wastewater. Environ Pollut. 82: 255-261.

45. Namasivayam C, Ranganathan K (1998) Effect of organic ligands on the removal of $\mathrm{Pb}(\mathrm{II})$, $\mathrm{Ni}(\mathrm{II})$, and $\mathrm{Cd}(\mathrm{II})$ by waste $\mathrm{Fe}(\mathrm{III}) / \mathrm{Cr}$ (III) hydroxide. Water Res 32: 969-971.

46. Gupta VK, Ali Imran (2002) Adsorbents for water treatment: Low cost alternatives to carbon, Encyclopaedia of surface and colloid science, (edited by Arthur Hubbard), Marcel Dekker, New York, USA Vol. 1: 136-166.

47 Altundogan HS, Altundogan S, Tumen F, Bildik M (2000) Arsenic removal from aqueous solutions by adsorption on red mud. Waste Manage. 20:761-767.

48 Zwain Haider M, Vakili Mohammadtaghi, Dahlan Irvan (2014) Waste Material Adsorbents for Zinc Removal from Wastewater: A Comprehensive Review. Int. J Chem Engg. 2014: $1-13$. 